\title{
Morphology and Properties of Electrospun PCL and Its Composites for Medical Applications: A Mini Review
}

\author{
Mokgaotsa Jonas Mochane ${ }^{1, *}{ }^{\mathbb{D}}$, Teboho Simon Motsoeneng ${ }^{2}$, Emmanuel Rotimi Sadiku ${ }^{3}{ }^{(0)}$, \\ Teboho Clement Mokhena ${ }^{4,5}$ (D) and Jeremia Shale Sefadi ${ }^{6, *}$ \\ 1 Department of Life Sciences, Central University of Technology, Free State, Private Bag X20539, \\ Bloemfontein 9301, South Africa \\ 2 Department of Chemistry, University of South Africa, Gauteng, Florida 1709, South Africa; \\ motsoenengts@gmail.com \\ 3 Institute of NanoEngineering Research (INER), Department of Chemical, Metallurgical and Materials \\ Engineering, Tshwane University of Technology, RSA, Pretoria 0001, South Africa; Sadikur@tut.ac.za \\ 4 CSIR Materials Science and Manufacturing, Polymers and Composites, Port Elizabeth 6000, South Africa; \\ mokhenateboho@gmail.com \\ 5 Department of Chemistry, Nelson Mandela University, Port Elizabeth 6031, South Africa \\ 6 School of Natural and Applied Sciences, Sol Plaatje University, Kimberley 8301, South Africa \\ * Correspondence: mochane.jonas@gmail.com (M.J.M.); jeremia.sefadi@spu.ac.za (J.S.S.)
}

Received: 2 April 2019; Accepted: 13 May 2019; Published: 29 May 2019

\begin{abstract}
Polycaprolactone (PCL) is one of the most used synthetic polymers for medical applications due to its biocompatibility and slow biodegradation character. Combining the inherent properties of the PCL matrix with the characteristic of nanofibrous particles, result into promising materials that can be suitable for different applications, including the biomedical applications. The advantages of nanofibrous structures include large surface area, a small diameter of pores and a high porosity, which make them of great interest in different applications. Electrospinning, as technique, has been heavily used for the preparation of nano- and micro-sized fibers. This review discusses the different methods for the electrospinning of PCL and its composites for advanced applications. Furthermore, the steady state conditions as well as the effect of the electrospinning parameters on the resultant morphology of the electrospun fiber are also reported.
\end{abstract}

Keywords: polycaprolactone; nanofibrous; electrospinning; morphology; surface area

\section{Introduction}

Polycaprolactone (PCL) is one of the most regularly used synthetic polymers for medical applications; this is due to the slow biodegradation and biocompatible characteristics that it displays [1-4]. A combination of the PCL properties (biocompatibility and slow biodegradation) with the unique feature of nanofibrous structure emanating from electrospinning can result in a promising material for different applications including medical applications. A number of different techniques, including the use of physical, chemical, thermal and electrostatic fabrications are often employed to produce polymeric nanofibers. Over the past 25 years, amongst the above mentioned techniques, electrospinning is the most extensively studied. Figure 1 demonstrates the number of annual publications related to the electrospinning of polymeric fibers, which shows that since 2003, the number of the annual publications related to "electrospinning", has grown from 10 to 3000 articles whilst electrospinning of PCL alone reached an approximation of 243 articles (for the year 2018). 


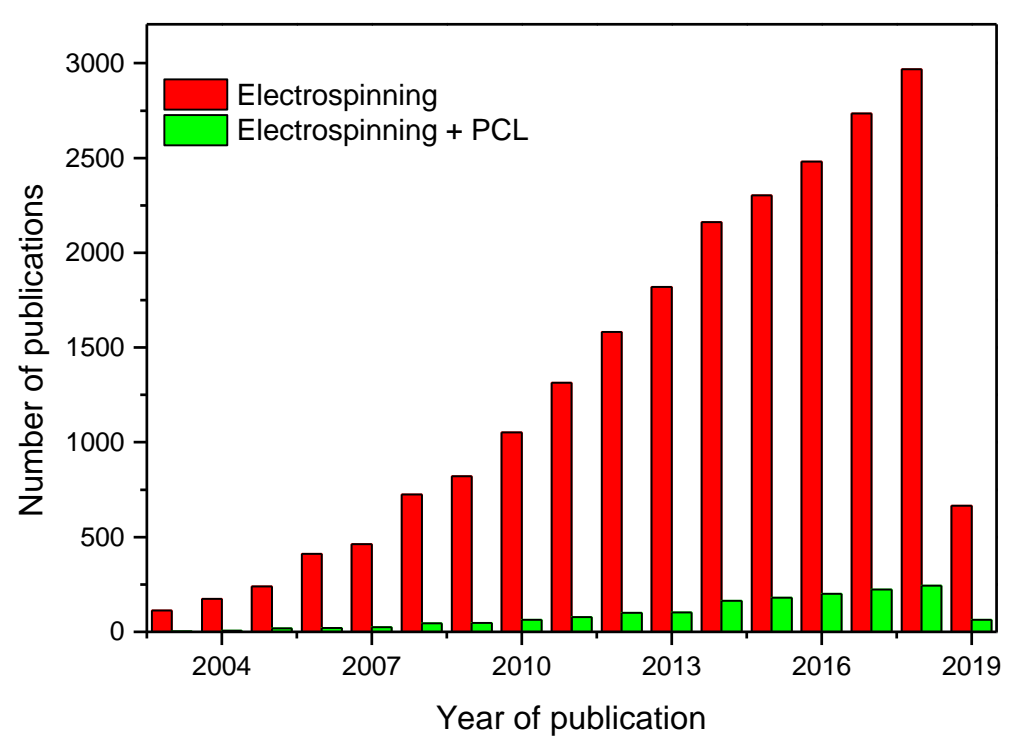

Figure 1. Number of published scientific papers related to electrospinning according to web of science (WoS) from 2003 to 2018 (2019) (date assessed, 13 March 2019).

Electrospinning is a flexible and interesting technology for the production of ultrafine fibers with diameter ranging from a few micrometers to sub-nanometers [5]. This technique can produce nano- or microfibers by applying an electrostatic field to a polymer solution, propelled by the supply of high voltage between a needle tip and a collector. Several studies have investigated the electrospinning of PCL [6-14]. For medical applications, it is important for PCL fiber to be without beads. This is important for medical applications because fiber diameters need to imitate the natural extra cellular morphology and, thus promote optimal cell growth. PCL has been electrospun by using different solvents, such as: chloroform, dichloromethane, dimethylformamide and methanol or a combination of the above solvents $[6,7,15]$. Amongst the above-mentioned solvents, chloroform is often employed as a solvent for electrospinning PCL, even though it has often, produced microfibers rather than nanofibers. This review summarizes the different solvents for electrospinning of PCL and its composites, with the aim of producing nanofibers on a nano scale, rather than on a micro scale. Furthermore, the different properties of electrospun PCL and PCL composites are summarized for medical applications.

\section{History of Electrospinning}

After a patented [16] article in 1934, electrospinning as a technique for the processing of fillers and polymers with well-controlled average size, porosity and morphology, to afford the resultant scaffolds, has been the subject of intense research. Usually, the modification of size and surface morphology of the components of polymer nanocomposites often yields a considerable improvement to a variety of properties in the field of polymer nanotechnology, especially when the ultimate nanocomposites are to be employed in medical practices [17-20]. Different techniques including melt blowing, force spinning, self-assembly, template synthesis and electrospinning account for the alteration of the diameter of fibers in the range of between micro- and nano-dimensions, in which the ultrafine fibrous membranes of polymer materials or fillers can be produced. In particular, the electrospinning method has been one of the most versatile treatment devices that can effectively afford sub-micro- or nano-dimension with large surface area-to-volume ratio, high porosity, flexibility and small size of various morphological orientation [21]. The polymer or filler solution thrusts out via the syringe needle under suffice electric field to generate the Taylor cone, which lands on the appropriate ground collector at a feasible distance, to produce the resultant membrane, as manifested in Figure 2. Moreover, the solution of the polymer composites, the collective mixture of the polymer and the filler solution, can be readily processed by the utilization of the electrospinning technique in order to manufacture the desired membranes 
that can be employed as sensors, air filtration, water treatment, energy generation and biomedical application [22-24]. By virtue of this intrinsic operation of the electrospinning process, there are internal and external factors that influence the ultimate functioning capability during the treatment of the fiber solution during the formation of the applicable membranes. Humidity, propelling voltage, viscosity of the solution, conductivity, number average molecular weight $\left(\overline{M_{n}}\right)$ of polymers and the solvent dissolution (solubility parameters), affect the throughput of the electrospun materials, specifically the morphology and the resultant properties $[25,26]$.

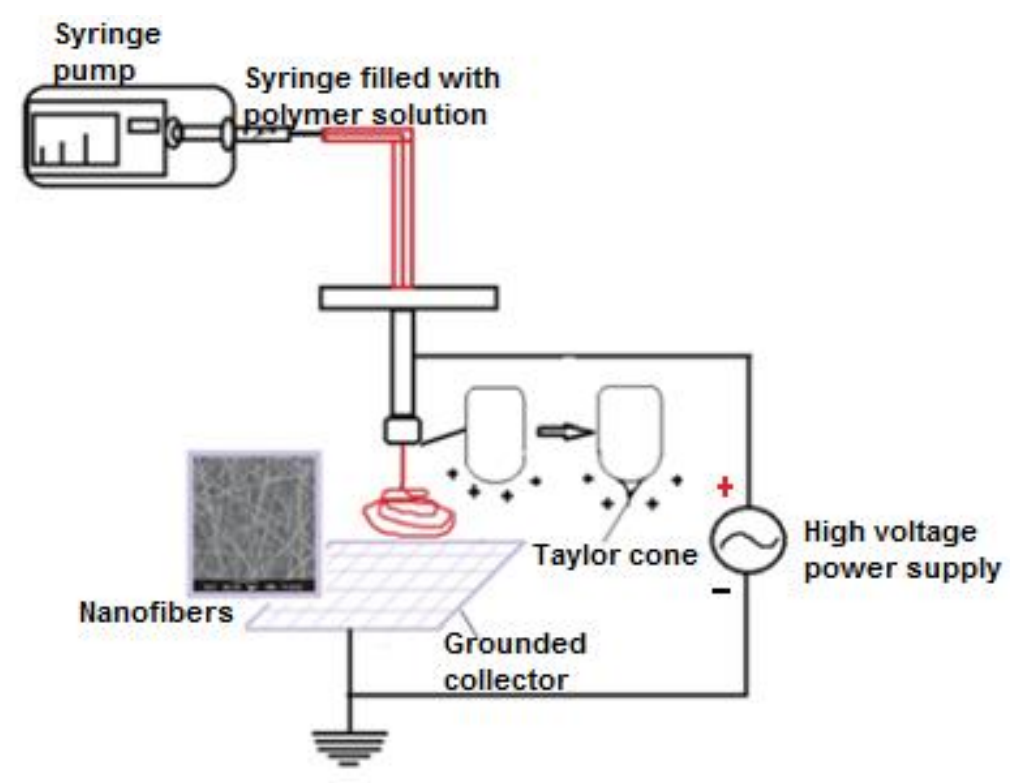

Figure 2. Illustration of a typical electrospinning process for the preparation of electrospun nanofibers.

\section{Electrospun Nanoparticles}

Due to its versatility, electrospinning is an extremely essential technique for the treatment of different fillers with disparate textural nature and properties, such as ceramic nanofibers, carbon nanofibers, whiskers and extracted natural polymer materials $[27,28]$. The fabrication of fillers by the electrospinning method, results in the altered nano-structural orientation of the resultant fibrous materials, which possess significantly reduced dimensional size in order to produce outstanding mechanical responses as well as the necessary and essential biomedical activities. The diversity of structural identity, emanating from the processing effect, induced by the electric field of the electrospinning process can be distinctly categorized as core-shell, bead, porous and ribbon fibers. These structural orientations are observed by examining the electric response of the individual thread of the fiber. However, when the threads of the fiber reorganize, upon the grounded collector, the mats of different structural orientations are formed and the architectural blueprint leads to the generation of beaded, random, aligned, patterned yarns and 3D structural nanofibers [28,29]. The electrospinning technique is the most preferred over others; on the account of its: (1) simplicity when utilized to a variety of materials and a very cost-effective method for nanofiber modification, (2) capacity to allow the introduction of bioactive compounds into the nanofibers and (3) utilization of the electrostatic force instead of heat during the processing of nanofibers, since heat can be detrimental to the structure of the highly thermal sensitive materials. Thus, the different nanofillers of disparate behavior and nativity can be, readily fabricated in order to afford nanofibers with desirable and efficient properties for various biomedical applications [30]. In recent years, a plethora of electrospun nanoparticles have been prepared by the electrospinning method in order to alter the dimensional size, for the formation of ultrafine nanofibers and also to attain a uniform porosity, which provides effective use in biomedical applications e.g., tissue engineering, wound dressing. For example, Lui and co-workers [28] prepared the 3D Ni-multiwall carbon nanotubes/carbon fibers by the electrospinning method in order 
to afford a smooth surface hybrid material with diameters ranging between $20-30 \mathrm{~nm}$, leading to a very efficient sensing capacity for detecting sarin nerve agent at $25^{\circ} \mathrm{C}$. Notwithstanding the impressive task that the electrospinning process possesses in the preparation of various nanomaterials with well-controlled nanofibrous size and refined porosity across the resultant membranes, factors such as the set-up for the electrospinning technique, conditions of an ambient environment and properties of the pristine nanoparticles, altogether, influence the diameters and the morphologies of the envisaged electrospun nanofibers.

In general, these electrospinning parameters have an inevitable effect on the properties of the ensuing electrospun scaffolds as well as the morphological features in which the bioactive characteristics can either be augmented or deteriorated, depending on the ultimate purpose in a particular organ of the living organism. By treating raw particles, inter alia, inorganic, organic, natural or synthetic materials; using the electrospinning process is equivalent to the structural modification and control of the surface area-to-volume ratio that will promote the bioactivity of the resultant nanoparticles for use in various in-vivo and/or in-vitro applications. In addition, the fabrication of bioactive particles via electrospinning methods and the subsequent use of these treated nanoparticles in the incorporation of the biocompatible polymer matrix like PCL has been intensively explored for the preparation of eletrospun mats with outstanding properties that condone the usability in the biomedical technology specifically for tissue regeneration due to the refined porosity with analogous average diameters found in human tissues. However, PCL as the matrix has limited applicability in biomedical practices because it cannot solely used to regenerate bone tissues due to the minimal stiffness, hydrophobicity and marginal bioactivity. Nonetheless, the use of bioactive materials together with PCL for the preparation of the electrospun mats has received great attention for novel development of membranes with superb cell proliferation and wound dressing [31-34]. For example, Correia and co-workers [35] investigated the use of extracted aloe vera chitosan nanofibrous materials and the subsequent fabrication using electrospinning method in the application of skin recovery and wound healing. It was discovered that the electrospun membranes promote the rapid cell proliferation and migration. Furthermore, these electrospun mats have antimicrobial activity, which is very vital for wound dressing or healing. The utilization of bioactive ceramic materials such as $\mathrm{TiO}_{2}$ and $\mathrm{Na}_{2} \mathrm{Ti}_{6} \mathrm{O}_{13}$ in the electrospinning method for the preparation of PCL nanocomposites membranes with plausible bioactivity from which the bone tissue regeneration can be established is an area of interest in medical society. Due to their abundance, insignificant toxicity and stable chemical structure, ceramic particles can be treated by the electrospinning technique to allow the formation of the membranes with viable stiffness and bioactive characteristics for cell proliferation and excellent production of bone structures $[34,36]$.

\section{Solvent Effect and Resultant Morphology of PCL}

In order to determine an optimum solvent system for the electrospinning of PCL, different solvents (single and binary solvent systems) were employed with the aim of obtaining bead-free nanofibers. The morphology of PCL electrospinning depends on the type of solvent, electrospinning parameters, concentration of the solvent, concentration of the polymer and the different solvent ratios employed. In the past, chloroform has been the most employed solvent for electrospinning of PCL; this is due to the solubility of PCL in chloroform. Van der Schueren and colleagues from Belgium [1] investigated on a suitable solvent system in order to obtain bead-free electrospun polycaprolactone (PCL) nanofibers. In their study, they investigated different single solvents (viz.: chloroform, formic acid and acetic acid) and binary solvents systems (viz.: formic acid/ethanol, formic acid/methanol, formic acid/chloroform, acetic acid/chloroform, acetic acid/ethanol, acetic acid/methanol and formic acid/acetic acid) for the electrospinning of PCL (morphology shown in Figure 3). It was reported that acetic acid as a solvent yielded droplets, whereas formic acid produced a fibrous structure that was composed of droplets (Figure 3c). Chloroform resulted in uniform, but thick fibers in the micro scale rather than fibers in the nanoscale range (Figure 3a). Formic acid/chloroform showed small fibers $(500 \mathrm{~nm})$, but there were some noticeable beads in the system (Figure 3a). However, an optimum binary solvent was found for 
formic acid/acetic acid with nanoscale fibers obtained with few beads. It was concluded that the fibers produced with formic acid/acetic acid (Figure 3e) were more than tenfold smaller than those produced when using chloroform as a solvent for PCL electrospinning.
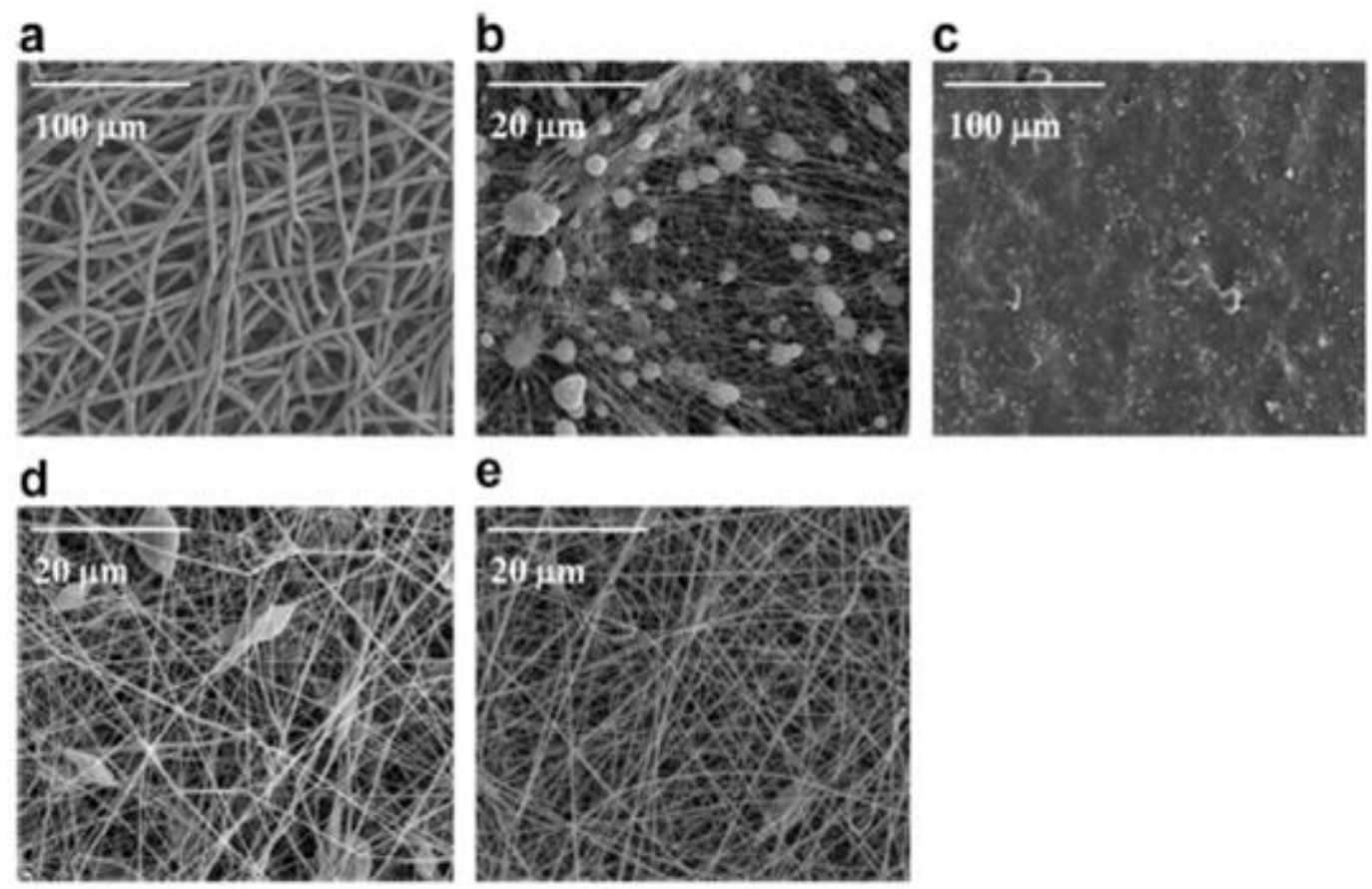

e

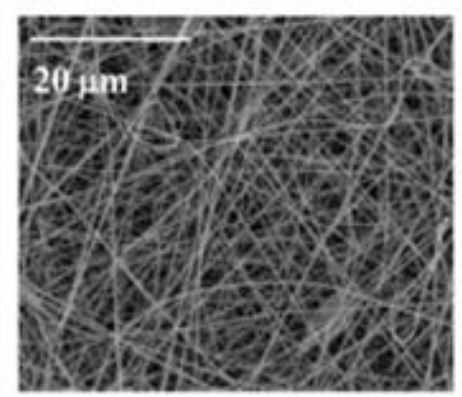

Figure 3. Images for various solvent systems: (a) chloroform, (b) formic acid, (c) acetic acid, (d) formic acid/chloroform (3:1), (e) formic acid/acetic acid (1:3), produced at 30\% RH [1]. Copyrights Elsevier.

Li et al. [37] examined the electrospinning of polycaprolactone (PCL) nanofibers by using water $\left(\mathrm{H}_{2} \mathrm{O}\right)$ as an additive in $\mathrm{PCL} /$ glacial acetic acid solution. Water $\left(\mathrm{H}_{2} \mathrm{O}\right)$, in this study, was not used as a solvent for PCL electrospinning, but it was employed for ionization of acetic acid and increases the conductivity. In this study, 17 to $23 \mathrm{wt} \%$ of PCL were prepared by dissolving PCL into glacial acetic acid. Optical microscopy (OM) images generally showed coarse features of the fibers, irrespective of the concentration of the solvent. When the concentration of PCL was $17 \mathrm{wt} \%$, large beads with diameters $\sim 15 \mu \mathrm{m}$ were obtained with an average diameter of $\sim 211 \mathrm{~nm}$. The authors observed continuous micro scale fibers with the absence of beads at $19 \mathrm{wt} \%$ of PCL. When the concentration of PCL was above $19 \mathrm{wt} \%$, thick microfibers with high viscosity were observed. The addition of water $\left(\mathrm{H}_{2} \mathrm{O}\right)$ on the fiber morphology was investigated by varying the water volume ratio (viz. 3 to $12 \mathrm{vol} \%$ ), while the concentration of PCL was kept at $17 \mathrm{wt} \%$. For the effect of water on the morphology and diameter, three parameters (viz: solution, process and ambient parameters) were key for electrospinning. The addition of water (6\%) in the PCL/glacial acetic acid (viz. $17 \mathrm{wt} \%$ of PCL) resulted in spindle-like thick fibers, which were different to the one obtained in the absence of water (large beads). When the concentration of water was increased to 9 and $12 \%$, thick spindle-like fibers with a diameter of $\sim 500 \mathrm{~nm}$ were obtained. According to the fiber size histograms reported, it was shown that the frequency of fibers over $500 \mathrm{~nm}$ was reduced with the increase in the $\mathrm{H}_{2} \mathrm{O}$ content. The fibers became more uniform when the content of $\mathrm{H}_{2} \mathrm{O}$ reached $9 \mathrm{vol} \%$ and above. Based on the morphology, stable solution conditions and the histogram results, the authors concluded that the $9 \mathrm{vol} \%$ of water would be the preferred content for ultrafine fiber production under stable conditions of electrospinning process. The optimum parameters for the production of electrospun PCL nanofibers were investigated [38]. In order to investigate the optimum solvent and PCL concentration, all other parameters were kept fixed. Binary solvents of formic acid/acetic acid (FA/AA) and formic acid/acetone (FA/A) were used at solvent ratios of formic acid (100\%), FA:AA 90:10, 70:30, 50:50, 30:70 and 10:90 as well as acetic 
acid at 100\% for electrospinning of PCL. The concentration of PCL was kept at 12.5, 15.0, 17.5 and $20.0 \%$. It was reported that the FA/AA solvent systems produced finer fibers when compared with FA/A, therefore, it was chosen as the solvent ratio system. The electrospun fibers fabricated at $12.5 \%$ of PCL showed a combination of both beads and droplets. As the concentration of PCL was increased (viz: 17.5 and $20.0 \%$ ), the fibers produced was observed to have helix-shaped micro-ribbons. This was attributed to an increase in concentration of PCL, which resulted in high amounts of entanglements. It was further recognized that amongst the above-mentioned FA/AA solvent ratios and PCL content, the optimum conditions for PCL nanofibers electrospinning was found to be 70:30 FA/AA solvent ratio with $15.0 \%$ PCL concentration. Table 1 summarizes the different solvent systems commonly used for the electrospinning of PCL.

Table 1. Selective solvent systems and morphologies of electrospinning of PCL.

\begin{tabular}{|c|c|c|}
\hline Solvent System & Morphological Results & Refs. \\
\hline $\begin{array}{l}\text { 1:1 tetrahydrofurane }(\mathrm{THF}) / \mathrm{N}, \mathrm{N} \text {-dimethylformamide } \\
(\mathrm{DMF})(\mathrm{w} / \mathrm{w}) \text { at concentration of } 15 \mathrm{wt} \%\end{array}$ & $\begin{array}{l}\text { SEM images of PCL fibers showed a smooth bead-less } \\
\text { fibrous structures }\end{array}$ & [39] \\
\hline $\begin{array}{l}\text { 1,1,1,3,3,3-hexafluoro-2-propanol to a concentration } \\
(10 \% \mathrm{w} / \mathrm{vol})\end{array}$ & $\begin{array}{l}\text { Anchoring of individual PCL fibers was confirmed by } \\
\text { optical microscopy images of the fibers before and after } \\
\text { manipulations. }\end{array}$ & [40] \\
\hline $\begin{array}{l}15 \mathrm{wt} \% \text { of PCL dissolved in } \mathrm{N}, \mathrm{N} \text {-dimethylformamide } \\
\text { (DMF) and dichloromethane (DCM) solvent mixture } \\
\text { at } 70: 30 \text { ratio: DMF:DCM }\end{array}$ & $\begin{array}{l}\text { PCL mat with an average diameter of } \sim 1.5 \mu \mathrm{m} \text { were } \\
\text { obtained. }\end{array}$ & [41] \\
\hline $\begin{array}{l}\text { PCL was electrospun with good solvents such as } \\
\text { chloroform (CF), dichloromethane (DCM), } \\
\text { tetrahydrofuran (THF) and formic acid (FA) were } \\
\text { used with poor solvent dimethylsulfoxide (DMSO) }\end{array}$ & $\begin{array}{l}\text { Porous structure consist of bead-free fibers having } \\
\text { average diameters of } 1470 \text { to } 2270 \mathrm{~nm} \text { was obtained } \\
\text { using } 12.5 \% \mathrm{v} / \mathrm{v} \text { PCL in CF/DMSO }\end{array}$ & [42] \\
\hline $\begin{array}{l}\text { PCL pellets was dissolved in a solvent mixture of } \\
\text { chloroform and dimethylformamide }(7: 3 \mathrm{v}: \mathrm{v})\end{array}$ & $\begin{array}{l}\text { Aligned and randomly oriented PCL nanofibers were } \\
\text { collected with different collectors }\end{array}$ & [43] \\
\hline $\begin{array}{l}\text { PCL was dissolved in } N, N \text {-dimethylformamide } \\
\text { (DMF), 1-methyl-2-pyrrolidone (NMP), } \\
\text { tetrahydrofuran (THF), chloroform (CF) and } \\
\text { dimethylsulfoxide (DMSO) }\end{array}$ & $\begin{array}{l}\text { When NMP, AC and DMF were employed as the } \\
\text { solvents for PCL electrospinning, PCL fibers showed } \\
\text { smaller fiber diameters than those of DCM, CF and THF }\end{array}$ & [44] \\
\hline PCL was dissolved in acetic acid & $\begin{array}{l}\text { Optical microscopy images showed coarse features of the } \\
\text { fibers. A } 17 \mathrm{wt} \% \text { concentration showed large beads with } \\
\text { diameters of about } 15 \mu \mathrm{m} \text { randomly spread. An increase } \\
\text { in concentration (viz } 19 \mathrm{wt} \% \text { ) resulted in large beads only }\end{array}$ & [37] \\
\hline $\begin{array}{l}\text { Formic acid/acetic acid (FA/AA) and formic } \\
\text { acid/acetone (FA/A) for electrospinning of PCL }\end{array}$ & $\begin{array}{l}\text { Finer fibers were obtained for formic acid/acetic acid } \\
\text { when compared with those produced by formic } \\
\text { acid/acetone solvent system. Optimum conditions for } \\
\text { PCL nanofibers electrospinning were produced for } 70: 30 \\
\text { FA/AA solvent ratio with 15\% PCL concentration }\end{array}$ & [38] \\
\hline
\end{tabular}

\section{Morphology of Electrospun PCL Blends and Composites}

In most cases, the electrospinning of PCL with other polymers or electrospun fibers has more of an advantage over pure electrospun PCL. The addition of another filler or electrospun polymer and fiber incorporated has been reported to improve the properties of PCL. Hassan et al. [45] investigated the production of nano hydroxyapatite/poly(caprolactone) composites for tissue engineering applications. In the absence of hydroxyapatite nanoparticles, PCL nanofibers fabricated at lower concentration $(\operatorname{viz} 7.5 \%(\mathrm{w} / \mathrm{v}))$ had beads, while those produced at higher concentration (viz 12.5\% $(\mathrm{w} / \mathrm{v}))$ were bead-less fibers with submicron dimensions. The addition of $n$ HA resulted in bead-less fibers without agglomerates, with the fibers thicker than those of PCL nanofibers. The development of electrospun 3D PCL/chitosan core-shell structure as scaffolds was studied for tissue engineering usage [46]. The composite was fabricated by utilizing coaxial electrospinning technique, whereby PCL was used as a core and chitosan as shell layer. The authors reported on bead-less and continuous core-shell micro/nano fibers. SEM images further showed that the scaffolds were biocompatible, which suggested that the $\mathrm{PCL} /$ chitosan will be a suitable candidate for scaffold in tissue engineering applications. Table 2 summarizes some selective morphologies of $\mathrm{PCL} / \mathrm{blends}$ and its composites for medical applications. 
Table 2. Selective studies on electrospinning of PCL blends and composites.

\begin{tabular}{|c|c|c|c|c|}
\hline $\begin{array}{c}\text { PCL Blend or } \\
\text { Composite System }\end{array}$ & Preparation (Solvent System) & Morphological Results & Application & Refs. \\
\hline Chitosan (CS)/PCL & $\begin{array}{l}\text { Both CS and PCL were dissolved in } \\
\text { formic acid/acetone mixture (70:30). All } \\
\text { CS/PCL solutions having different } \\
\text { concentrations were electrospun at room } \\
\text { temperature }\end{array}$ & $\begin{array}{l}\text { PCL was kept at } 6 \% \text { and CS was } \\
\text { concentration was varied from } 0.5 \% \\
\text { to } 2 \% \text {. In the concentration of } 0.5 \% \\
\text { three concentrations of CS/PCL i.e., } \\
\text { 1:3, } 1: 1 \text { and } 3: 1 \text { were electrospun. The } \\
\text { 1:3 composition showed fine } \\
\text { nanofibers with uneven morphology. } \\
\text { The increase in CS concentration to } 1: 1 \\
\text { and } 3: 1 \text { resulted in highly beaded } \\
\text { fibers. Furthermore, CS was kept at a } \\
\text { fixed concentration of } 1 \% \text { and PCL } \\
\text { was varied from } 4 \% \text { to } 10 \% \text {. At } 4 \% \\
\text { PCL, both } 1: 3 \text { and } 1: 1 \text { compositions of } \\
\text { CS/PCL gave a beaded fibrous } \\
\text { structure. The } 3: 1 \text { concentration } \\
\text { resulted in beaded and irregular fibers }\end{array}$ & $\begin{array}{l}\text { Electrospun } \\
\text { scaffold would be } \\
\text { applied for } \\
\text { biomedical } \\
\text { applications }\end{array}$ & [47] \\
\hline $\begin{array}{l}\text { PCL/hydroxyapatite } \\
\text { (HA)/AZ31/HA }\end{array}$ & $\begin{array}{l}\text { PCL/HA was dispersed in } \\
\text { chloroform-methanol ( } 3: 1 \mathrm{v} / \mathrm{v}) \text { mixture. } \\
\mathrm{HA} \text { nanoparticles were added to } \mathrm{AZ} 31 \\
(2.9 \% \mathrm{Al}, 0.88 \% \mathrm{Zn}, 0.001 \% \mathrm{Fe}, 0.02 \% \mathrm{Mn} \\
\text { and the remaining was } \mathrm{Mg} \text { ) by friction } \\
\text { stir processing to fabricate } \mathrm{AZ} 31 / \mathrm{HA} \\
\text { metal composite. The } \mathrm{HA} / \mathrm{AZ} 31 \text { was } \\
\text { treated with nitric acid }\left(\mathrm{HNO}_{3}\right) \text { and } \\
\text { coated with PCL/HA by electrospinning }\end{array}$ & $\begin{array}{l}\text { SEM images showed cell adhesion } \\
\text { and proliferation. }\end{array}$ & $\begin{array}{l}\text { Degradable } \\
\text { implant } \\
\text { applications }\end{array}$ & [48] \\
\hline PCL/gelatin & $\begin{array}{l}\text { Electrospun nanofibrous membranes with } \\
\text { different compositions of PCL and gelatin } \\
\text { were prepared first. Then membranes } \\
\text { were cross-linked by genipin }\end{array}$ & $\begin{array}{l}\text { SEM and AFM images showed that } \\
\text { the nanofibers possessed uniform and } \\
\text { smooth structures in two (2D) and } \\
\text { three (3D) dimension. The average } \\
\text { diameters of the nanofibers were in } \\
\text { the region of } 200-600 \mathrm{~nm} \text {. The } \\
\text { addition of gelatin to PCL improved } \\
\text { adhesion and proliferation }\end{array}$ & $\begin{array}{l}\text { Guided bone } \\
\text { regeneration (Bone } \\
\text { tissue engineering) }\end{array}$ & [49] \\
\hline $\begin{array}{l}\text { PCL/gelatin and } \\
\text { PCL/collagen } \\
\text { nanofibers }\end{array}$ & $\begin{array}{l}\text { Two polymer solutions with different } \\
\text { solvents were prepared. One of the } \\
\text { solutions was prepared with } \\
\text { hexafluoroisopropanol (HFIP) and the } \\
\text { other solution with acetic acid (AA)and } \\
\text { formic acid (FA) mixture at 9:1 ratio } \\
\text { (AA:FA). Polymer concentration was kept } \\
\text { at } 5 \% \text { w/w for solutions prepared with } \\
\text { HFIP and } 15 \% \text { w/w for AA/FA mixture. } \\
\text { PCL:gelatin ratios were kept } 9: 1,8: 2 \text { and } \\
7: 3 \text {, while PCL:collagen was kept at } 9: 1 \text {. } \\
\text { All materials were electrospun at the } \\
\text { same temperature range }\left(22-24{ }^{\circ} \mathrm{C}\right) \text { and } \\
50-55 \% \text { humidity }\end{array}$ & $\begin{array}{l}\text { SEM images showed that the } \\
\text { electrospun fibers had similar } \\
\text { morphology irrespective of the } \\
\text { solvent used even after } 90 \text { days of } \\
\text { biodegradation. It was further } \\
\text { observed from SEM analysis that the } \\
\text { nanofibers electrospun from AA/FA } \\
\text { biopolymer were present in the form } \\
\text { strings more exposed to leaching than } \\
\text { those nanofibers electrospun from } \\
\text { perfluorinated alcohols }\end{array}$ & Tissue engineering & [50] \\
\hline PCL/gelatin & $\begin{array}{l}\text { PCL/gelatin solution was fabricated by } \\
\text { dissolving PCL and gelatin in } \\
\text { trifluoroethanol (TFE). Polymer } \\
\text { concentration was kept at } 6 \text { wt. } \% \text { and the } \\
\text { composition of PCL:gelatin was } 8: 2\end{array}$ & $\begin{array}{l}\text { SEM images showed smooth and } \\
\text { uniform distribution of nanofibers } \\
\text { with interconnected pores with no } \\
\text { aggregation }\end{array}$ & $\begin{array}{l}\text { Artificial } \\
\text { periosteum }\end{array}$ & [51] \\
\hline
\end{tabular}

\section{Biomedical Indispensability of the PCL Electrospun Nanocomposites}

The preparation of PCL nanocomposites by the electrospinning method in order to afford a smooth surface of the nanocomposites materials with large surface area-to-volume ratio, exclusive properties and required applicability, have been intensely explored in the last decades [25,27,30,48,52-82]. PCL as a quintessential synthetic thermoplastic that possesses extremely outstanding properties, such as sluggish rate of biodegradability, biocompatible towards numerous materials, thermal stability and can be readily modified. On the account of these phenomenal facets, PCL has been considered as a superb biomaterial, which can be employed in various biomedical applications (viz., scaffolds for tissue re-engineering, wound dressing and targeted drug delivery systems) [25,52,53]. In addition, the incorporation of a foreign nanoparticle into the PCL matrix can result in the alteration of virtually all the native properties of PCL and account for a specific improvement in which the biomedical utility 
of the resultant PCL/nanofiber composites can be broadly expanded. Notwithstanding the excellent properties of the synthetic PCL thermoplastic and the type of nanofiller introduced into its matrix, electrospinning method has proved to be pertinent for the preparation of PCL/fiber nanocomposites, with desirably envisaged properties for specific applications in the biomedical practices, particularly in the in-vivo cures [20]. The ternary system of $\mathrm{PCL} /$ graphene oxide/ $\mathrm{Fe}_{3} \mathrm{O}_{4}$ nanocomposites was prepared by using electrospinning methodology at a constant concentration of $\mathrm{Fe}_{3} \mathrm{O}_{4}$ and varying contents of graphene oxide; it was reported that the living cells decreased with the increase of the graphene oxide due to its large surface area, triggered by an increase in the average diameter of the nanofiber [48]. Recently, a considerable amount of research has been conducted on the preparation of different electrospun PCL/nanofiber composites in order to assess the potential biomedical applications in remedying of ailments or for tissue engineering for both in-vivo and in-vitro classifications [49].

For example, Kim and Kim [71] conducted the preparation of PCL/collagen electrospun membranes for use in the wound healing applications. It was reported that the orientation of nanofibers is responsible in facilitating the regeneration of epithelial tissues in order to expedite the healing process of the wounds. The water contact analysis indicated the rapid water uptake, which suggests that the prepared mats can increase the cell adhesion around the affected area. Thus, due to an increased proliferation of the cells, the re-epithelialization phenomenon leads to a swift healing process of the wounds. Figure 4 displays the in-vivo treatment for the healing process of the wound by dressing scarred places with the electrospun PCL/collagen mats.
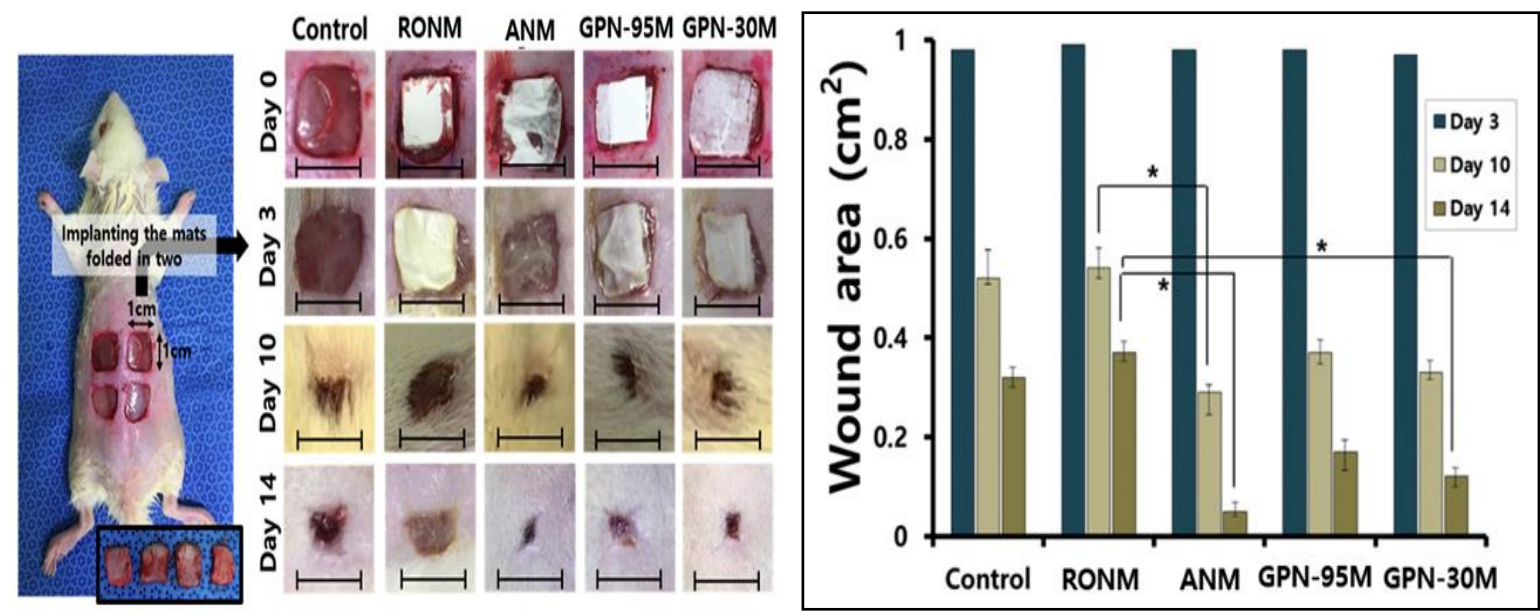

Figure 4. The healing process relative to time of the applied PCL/collagen mats on the rat wound. Left: Comparison of wound closure among five groups. Right: Wound areas at different day points after grafting [71]. Copyrights Elsevier.

The treatment of PCL/alginate nanocomposites using external electric fields of different capacity will serve as an impetus in the applications of drug delivery, especially for transfection in cell immobilization efficiency. Alginate has been recently considered as one of the most effective nanofibers in biomedical practices on the account that it is able to reduce cytotoxicity and alleviate excessive adsorption imminent between serum protein and cationic polyplexes, therefore this phenomenon will stimulate the transfection for in situ applications. The degradation rates can be controlled by treating PCL/alginate scaffolds with external electric fields so that they could be amenable for the gene immobilization for both gene delivery and tissue regeneration applications. Hu and Ting [74] reported the effect of the treatment of PCL/alginate mats by using external electric fields at different voltages in order to regulate the degradation rate of the scaffolds for the benefit in tissue regenerative applications. It was outlined that the increase of applied voltage reduces the transfection efficiency of scaffolds, thus manipulates the gene transportation caused by gene immobilization capacity. The 
control of the voltage within the range of $0.5 \mathrm{~V}$ to $1 \mathrm{~V}$ was found to be essential in providing the excellent effectiveness for gene transfection properties according to Figure 5.

In recent years, a plethora of PCL/nanofibers and PCL-blend/nanofibers mats prepared by electrospinning technique for use in different biomedical applications including drug delivery, tissue regeneration and cell proliferation has been reported in the literature. The following table collates the indispensability of the electrospun PCL/nanofiber composites, induced by different nanoparticles of various properties and their potential biomedical applications. Selective studies on different nanofillers, component systems and average diameters, are tabulated in Table 3.

Table 3. Different nanofillers, component systems, biomedical applications and the average diameters of the electrospun. PCL/fiber nanocomposites.

\begin{tabular}{|c|c|c|c|c|}
\hline \multicolumn{5}{|c|}{ Electrospun PCL/Fiber Nanocomposites } \\
\hline Nanofiller(s) & System & Biomedical Application & Average Diameter (nm) & Refs. \\
\hline Processed PCL & Mono & Fast dissolving drug delivery & $0.34-1.56 \times 10^{-3}$ & [25] \\
\hline Chitosan & Binary & Tissue engineering & $400-4 \times 10^{-3}$ & [27] \\
\hline Hydroxyapatite (Ti coated) & Binary & $\begin{array}{c}\text { Drug delivery, bone tissue } \\
\text { engineering }\end{array}$ & 100 & [30] \\
\hline AZ31/hydroxyapatite & Ternary & $\begin{array}{l}\text { Biomineralization (temporary } \\
\text { implants) }\end{array}$ & 600 & [48] \\
\hline Cellulose nanocrystals & Binary & Drug delivery & 233 & [52] \\
\hline Nanodiamond & Binary & $\begin{array}{l}\text { Proliferation of epithelial cells } \\
\text { (wound healing) }\end{array}$ & $300-600$ & [53] \\
\hline Gelatin/Lawsone & Ternary & Wound healing, cell proliferation & $238-297$ & [56] \\
\hline Nanosilicates & Binary & Bone tissue engineering & $241-321$ & [57] \\
\hline Silk fibroin & Binary & Cell proliferation, tissue engineering & $217-25$ & {$[58,59]$} \\
\hline Encapsulated PCL & Mono & Drug delivery & $804 \pm 390$ & [60] \\
\hline Gelatin/graphene & Ternary & Cell proliferation & 185 & [61] \\
\hline Zein/gum Arabic & Ternary & $\begin{array}{l}\text { Skin tissue regeneration, antibacterial } \\
\text { activity }\end{array}$ & $367-645$ & [62] \\
\hline Chitosan/ $/ \mathrm{SrAl}_{2} \mathrm{O}_{4}: \mathrm{Eu}^{2+} \mathrm{Dy}^{3+}$ & Ternary & Retinal tissue engineering & 50 & [63] \\
\hline Layered double hydroxide & Binary & $\begin{array}{l}\text { Tissue engineering, adipogenic } \\
\text { differentiation }\end{array}$ & $0.1-1.2 \times 10^{-3}$ & [64] \\
\hline $\begin{array}{l}\text { Pluronic F127/nano } \\
\text { hydroxyapatite }\end{array}$ & Ternary & Metallic implants (oesteo-integration) & 534 & [65] \\
\hline $\mathrm{ZnO}$ & Binary & Antibacterial properties & $1.019-0.511 \times 10^{-3}$ & {$[66]$} \\
\hline Collagen/elastin & Ternary & Tissue engineering & $310-693$ & {$[67]$} \\
\hline Gelatin & Binary & Tissue engineering & $584 \pm 337$ & {$[67,68]$} \\
\hline Bioactive glass & Binary & $\begin{array}{c}\text { Osteogenic, angiogenic and } \\
\text { antibacterial potential }\end{array}$ & $346-532$ & [69] \\
\hline Collagen & Binary & $\begin{array}{c}\text { Neovascularization and } \\
\text { reepithelization }\end{array}$ & $2.6-4.9 \times 10^{-3}$ & [71] \\
\hline Vitamin E & Binary & Antioxidant properties & - & {$[72]$} \\
\hline Chitosan/hydroxyapatite & Ternary & Tendon and ligament regeneration & 200 & [73] \\
\hline Alginate & Binary & Gene immobilization and transfection & - & {$[73-75]$} \\
\hline Reduced graphene oxide & Binary & $\begin{array}{l}\text { Biomineralization, osteogenic and cell } \\
\text { proliferation }\end{array}$ & $380-410$ & [76] \\
\hline Silicon nanoparticles & Binary & Camptothecin delivery & $161 \pm 58$ & [77] \\
\hline Geranyl cinnamate & Binary & Drug delivery & $186.8 \pm 6.2$ & {$[78]$} \\
\hline Triclosan & Binary & Drug delivery, antibacterial activity & $40-60 \times 10^{-3}$ & [79] \\
\hline Dipyridamole & Binary & Endothelial cell growth & $604-816 \times 10^{-3}$ & [80] \\
\hline F127 & Binary & Esophageal tissue repair & $36 \times 10^{-3}$ & [81] \\
\hline Human serum albumin & Binary & Tissue regeneration & $356 \pm 70$ & [82] \\
\hline
\end{tabular}




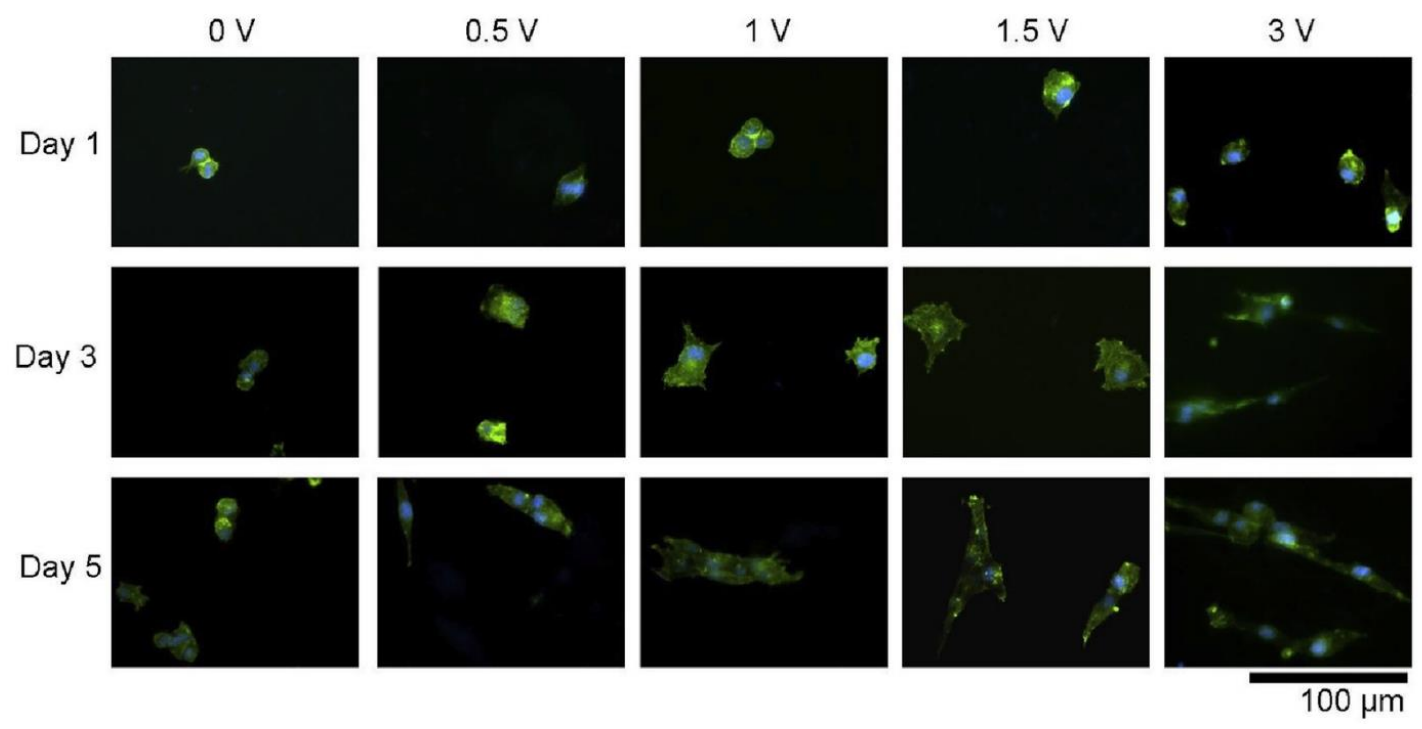

Figure 5. The effect of applied voltage on the control of the gene immobilization efficiency for electrospun PCL/alginate scaffolds [74]. Copyrights Elsevier.

\section{Mechanical Properties of Electrospun PCL and Its Composites}

The intrinsic mechanical properties of synthetic PCL thermoplastic can be improved by the incorporation of foreign nanoparticles to form the PCL/fiber composites that can be utilized in various applications of biomedical practices. In addition, the preparation of PCL/fiber composites by electrospinning technique provides an added enhancement on the ultimate mechanical properties due to its facile preparatory set-up and the formation of well-dispersed nanofibers with uniform average diameter throughout the PCL matrix. Electrospun PCL/filler composites have shown exclusive improvement in various mechanical properties, namely: flexural strain, tensile strain, tensile stress, Young's modulus and thermomechanical strength $[56,58,70,79]$. These mechanical properties are closely associated with the biomedical treatments, particularly in the implantation of artificial bone and muscle tissues regeneration, on the account that the stiffness of the electrospun PCL/fiber composites is relatively appropriate for in-vivo applications [72]. Different fillers of disparate properties can be treated, prior to incorporation into the synthetic PCL matrix in order to obtain the resultant PCL/filler composites with outstanding mechanical properties in which the horizon of applicability of PCL composites is vastly widened $[57,82]$. In addition, the blending of PCL with other synthetic polymers with different properties for the preparation of polymer blends, after which the fabricated fillers can be introduced to the blends to afford PCL/blends composites with tremendous enhancement of the mechanical properties $[79,83,84]$. Table 4 summarizes the different solvent systems for electrospinning of PCL/filler nanocomposites and their mechanical properties [27,52,56,58,62-64,67,72,80,82,84-89].

Table 4. Different solvent systems, mechanical properties of the electrospun PCL/fiber composites.

\begin{tabular}{|c|c|c|c|}
\hline Solvent System & $\begin{array}{c}\text { PCL/Filler } \\
\text { Nanocomposites }\end{array}$ & Mechanical Properties and Observations & Refs. \\
\hline Dimethylformamide/chloroform & PCL/Chitosan nanofibrils & $\begin{array}{l}\text { Ultimate tensile strength and Young's modulus show the } \\
\text { increasing trend with the increase in the chitosan } \\
\text { nanofibrils content to the highest values of } 32.9 \mathrm{MPa} \pm 4.4 \\
\text { and } 6.03 \mathrm{MPa} \pm 0.65 \text { at } 10 \% \text {, respectively. The increase in } \\
\text { Young's modulus is due to the interaction between the } \\
\text { inter-molecular chains of CN and PCL. Elongation at break } \\
\text { presented a general decrease with the incorporation of } \\
\text { chitosan nanofibrils reaching the minimal value of } 44 \mathrm{MPa} \\
\pm 15 \text { at } 7.5 \% \text {. This observable decrease is explained by the } \\
\text { stiffening effect arising from the intrinsic structure of } \mathrm{CN} \text {. }\end{array}$ & [27] \\
\hline
\end{tabular}


Table 4. Cont.

\begin{tabular}{|c|c|c|c|}
\hline Solvent System & $\begin{array}{c}\text { PCL/Filler } \\
\text { Nanocomposites }\end{array}$ & Mechanical Properties and Observations & Refs. \\
\hline Acetic acid & $\begin{array}{l}\text { PCL/Cellulose } \\
\text { nanocrystals }\end{array}$ & $\begin{array}{l}\text { The Young's modulus increased significantly from } 23 \mathrm{MPa} \\
\pm 3.9 \text { to } 43 \pm 2.3 \mathrm{MPa} \text { pristine PCL to } 1 \% \text { of cellulose } \\
\text { nanocrystals }(\mathrm{CNCs}) \text { but decreased to } 39.0 \pm 5.9,39.6 \pm 1 \\
\text { and } 27.8 \pm 3.9 \text { for } 1.5 \%, 2.5 \text { and } 4 \% \text { contents, respectively. } \\
\text { This is due to the agglomeration of the CNCs at higher } \\
\text { contents within the PCL nanofiber creating the stress } \\
\text { abetting areas. However, the tensile strength and strain } \\
\text { showed a general increase with increasing the } \\
\text { concentration of CNCs probably due to the existence of the } \\
\text { amorphous region. }\end{array}$ & [52] \\
\hline Dimethylformamide & $\begin{array}{l}\mathrm{PCL} / \text { Graphene } \\
\text { oxide/ } / \mathrm{Fe}_{3} \mathrm{O}_{4}\end{array}$ & $\begin{array}{l}\text { Both the elongation at break and tensile strength increase } \\
\text { gradually with the increase of graphene oxide }(\mathrm{GO}) \text { whilst } \\
\mathrm{PCL} / \mathrm{Fe}_{3} \mathrm{O}_{4} \text { ratio remains constant at } 10: 1 \text {. The increase of } \\
\text { these mechanical properties is due to the uniform } \\
\text { distribution of } \mathrm{GO} \text { in the composites of } \mathrm{PCL} / \mathrm{Fe}_{3} \mathrm{O}_{4} \text {, and } \\
\text { also the strong interfacial adhesion between the } \\
\text { components of the electrospun mats. }\end{array}$ & [54] \\
\hline Dimethylformamide & PCL/Lawsome/Gelatin & $\begin{array}{l}\text { PCL/Gel shows highest tensile strength of } 2.14 \pm 0.3 \mathrm{MPa} \text {, } \\
\text { Young's modulus of } 2.12 \pm 0.9 \mathrm{MPa} \text { and strain of } 37 \% \pm \\
6.6 \% \text {. Addition of lawsome notably reduced tensile } \\
\text { strength to } 1.7 \pm 0.9,1.217 \pm 1.4 \text { and } 0.84 \pm 0.8 \mathrm{MPa} \text { for } 0.5,1 \\
\text { and } 1.5 \% \text { concentrations, respectively, and Young's } \\
\text { modulus also decreased from } 1.9 \pm 1.1 \mathrm{MPa} \text { and } 1.38 \pm 0.6 \\
\text { MPa for } 0.5 \% \text { and } 1.5 \% \text {. The sample presented a drastic } \\
\text { decrease of tensile strength by } 91 \% \text { from dry to wet } \\
\text { condition accordingly. The diminishing of the mechanical } \\
\text { properties is due to the plasticization arising from the } \\
\text { incorporation of lawsome nanofiller. }\end{array}$ & [56] \\
\hline Formic acid & PCL/Silk fibroin & $\begin{array}{l}\text { Elastic modulus increased from pure PCL fiber of } 21.6 \mathrm{MPa} \\
\pm 1.7 \text { to } 49.3 \mathrm{MPa} \pm 6 \text { and } 98.1 \mathrm{MPa} \pm 23.7 \text { at } 20 \mathrm{wt} \% \text { and } 40 \\
\text { wt } \% \text {, respectively. Elongation at break decreased by } \\
\text { roughly } 50 \% \text { from for both nanocomposites with the } \\
\text { incorporation of silk fibroin. But the tensile strength } \\
\text { remained virtually unchanged with the addition of the silk } \\
\text { fibroin. }\end{array}$ & [58] \\
\hline Acetic acid/formic & PCL/Zein/Gum Arabic & $\begin{array}{l}\text { Elongation at break and tensile strength of the electrospun } \\
\text { fibers increase due to the moisture quantity of gum Arabic } \\
\text { (GA) leading to the additional elasticity. Also, the presence } \\
\text { of hydroxyl groups in GA and PCL causes the hydrogen } \\
\text { bonding in which the tensile strength is likely enhanced. }\end{array}$ & [62] \\
\hline Dimethylformamide/chloroform & $\begin{array}{c}\mathrm{PCL} / \text { Chitosan/ } \\
\mathrm{SrAl}_{2} \mathrm{O}_{4}: \mathrm{Eu}^{2+} \mathrm{Dy}^{3+}\end{array}$ & $\begin{array}{l}\text { An increase in the nanophosphor concentration has } \\
\text { considerably increased the tensile strength due to the } \\
\text { reduction of ductility of the PCL nanocomposites. The } \\
\text { observed flexibility at particularly } 30 \% \text { nanophosphor } \\
\text { content displays the strain capability analogous to that of } \\
\text { retinal tissue. }\end{array}$ & [63] \\
\hline Dimethylformamide & $\begin{array}{l}\text { PCL/Layered double } \\
\text { hydroxide }\end{array}$ & $\begin{array}{l}\text { The tensile strength and tensile strain increase with the } \\
\text { incorporation of nanoclay at } 0.1 \% \text { and } 1 \% \text {, but manifested a } \\
\text { dramatic decrease at } 10 \% \text {. This is largely due to the } \\
\text { diameter distribution and presence of stress accelerators } \\
\text { emanating from overloaded PCL fiber. Young's modulus } \\
\text { presented the gradual decreasing trend with the increase of } \\
\text { the nanoclay until to } 2.38 \mathrm{MPa} \text { at } 10 \% \text { content. }\end{array}$ & [64] \\
\hline
\end{tabular}


Table 4. Cont.

\begin{tabular}{|c|c|c|c|}
\hline Solvent System & $\begin{array}{c}\text { PCL/Filler } \\
\text { Nanocomposites }\end{array}$ & Mechanical Properties and Observations & Refs. \\
\hline Acetic acid/dimethylsulphoxide & PCL/Chitosan & $\begin{array}{l}\text { Young's modulus shows a favourable increase of about } \\
215.5 \mathrm{MPa} \text {, which is in analogous range with the tendon } \\
\text { rigidity at the acceptable ligament regeneration load of } 250 \\
\text { MPa. }\end{array}$ & [72] \\
\hline Chloroform & PCL/Graphene/Nanotube & $\begin{array}{l}\text { There is a significant increase of the Young's modulus with } \\
\text { the incorporation of graphene/nanotube at } 0.5 \% \text { and } 1 \% \\
\text { because of the uniform dispersion of the PCL fiber. }\end{array}$ & [86] \\
\hline Dimethylformamide & PCL/Cellulose nanofibers & $\begin{array}{l}\text { Elongation at break and the tensile strength increase with } \\
\text { increasing the cellulose nanofibers content, reaching the } \\
\text { maximum at } 1 \% \text {, after which it decreases with further } \\
\text { increase at } 5 \% \text { due to the self-agglomeration of the } \\
\text { aggregates at higher concentration by virtue of } \\
\text { hydrophobicity of the matrix. }\end{array}$ & [87] \\
\hline Acetic acid & PCL/F127 & $\begin{array}{l}\text { Young's modulus of E-jetted scaffold, hierarchical scaffold } \\
\text { and TIPS PLLC show a comparable values of } 6.1 \mathrm{MPa} \pm 0.8 \text {, } \\
6.6 \mathrm{MPa} \pm 0.2 \text { and } 6.67 \mathrm{MPa} \text {, respectively. Accordingly, the } \\
\text { ultimate tensile strength displayed } 0.7 \mathrm{MPa} \pm 0.3,0.5 \mathrm{MPa} \\
\pm 0.1 \text { and } 1.8 \mathrm{MPa} \pm 0.3 \text {. }\end{array}$ & [82] \\
\hline Acetic acid/formic acid & PCL & $\begin{array}{l}\text { Elastic modulus is of pristine PCL and the plasma treated } \\
\text { PCL remain unchanged at } 6 \mathrm{MPa} \text {. }\end{array}$ & [88] \\
\hline Acetic acid/formic acid & PCL/Gelatin & $\begin{array}{l}\text { Loss modulus increased with the addition of gelatin into } \\
\text { the PCL because of the weak interaction and poor affinity } \\
\text { between two components of the nanocomposites. }\end{array}$ & [89] \\
\hline \multicolumn{4}{|c|}{ Electrospun PCL/Blend Fiber Nanocomposites } \\
\hline Melt electrospinning & PCL/LATC30 & $\begin{array}{l}\text { Loss and storage moduli increase with the incorporation of } \\
\text { LAT30 into the PCL matrix due to the long relaxation time } \\
\text { and improved elasticity, which control the movement of } \\
\text { polymer chains in the blend mats. }\end{array}$ & [80] \\
\hline Chloroform/methanol & PCL/PGS/Gelatin & $\begin{array}{l}\text { Elongation at break increases from } 36.8 \mathrm{MPa} \pm 4 \text { to } 102.0 \\
\mathrm{MPa} \pm 4 \text { in dry and wet conditions, respectively. Also, the } \\
\text { tensile strength shows an increase by } 0.74 \mathrm{MPa} \pm 0.24 \text { and } \\
1.61 \mathrm{MPa} \pm 0.1 \text { for wet and dry conditions accordingly. The } \\
\text { elastic modulus displays a decrease by nearly } 81 \% \text { from dry } \\
\text { to wet medium. The introduction of less rigid gelatin } \\
\text { accounts for the modulus strength close to intrinsic } \\
\text { myocardium. }\end{array}$ & [84] \\
\hline Hexafluoroisopropanol & PCL/PLGA/Tenofovir & $\begin{array}{l}\text { The tensile strength and Young's modulus showed } \\
\text { infinitesimal changes with the addition of tenofovir. The } \\
\text { incorporation of tenofovir has insignificant effect on the } \\
\text { general mechanical properties of the electrospun } \\
\text { PCL/PLGA blend. }\end{array}$ & [85] \\
\hline
\end{tabular}

\section{Conclusions and Future Remarks}

Generally, electrospinning is a technique that produces non-woven fibers in the magnitude of a few nanometers with large surface areas, which allows an easy functionalization for a variety of purposes and grant excellent mechanical properties. Due to its simplicity and viable setup of parameters, electrospinning has gained an enormous interest in the production of large-scale nanofibers in various applications. The electrospinning technique is vastly utilized in the field of biomedical technology for both in-vivo and in-vitro treatments, and most synthetic biopolymers of different structural compositions are electrospun in order to meet the standards of biomedical applications. Polycaprolactone is one of the most widely used biodegradable polymers for the modification of new materials purported for use in medical fields for tissue regeneration. Solvent system comprised of binary solvent components manifested a magnificent potential of processing PCL solution via electrospinning method in comparison to the single solvent system. Binary solvents have provided a breakthrough in terms of smaller fiber diameters when compared with the commonly used solvent in the form of chloroform. Electrospun PCL/filler composites have shown improvement in mechanical properties, which is a key for biomedical treatments, particularly in the implantation of artificial bone and muscle tissues regeneration. It is noted from studies that solvents are key to electrospinning and in future, 
solvents issues, such as biocompatibility and suffocating smell, should be taken in consideration. It is advised that the process of electrospinning be appropriately conducted in well-ventilated fume-hoods with excellent operational conditions, and the temperature should be adequately considered.

Author Contributions: E.R.S. and M.J.M. co-designed and guided a mini-review as well as co-wring Sections 1 and 2 of the article; T.S.M. and T.C.M. co-wrote Sections 3, 4 and 6; J.S.S. wrote Section 5; while T.S.M. and M.J.M. compiled the article together.

Funding: This research was funded by National Research Funding (NRF) Thuthuka, South Africa.

Acknowledgments: The authors would like to thank the financial support by National Research Funding (NRF) Thuthuka.

Conflicts of Interest: The authors declare no conflict of interest.

\section{References}

1. Schueren, L.V.D.; Schoenmaker, B.D.; Kalaoglu, O.I.; Clerk, K.D. An alternative solvent system for the steady state electrospinning of polycarbonate. Eur. Polym. J. 2011, 47, 1256-1263. [CrossRef]

2. Agarwal, S.; Wendorff, J.H.; Greiner, A. Use of electrospinning technique for biomedical applications. Polymer 2008, 49, 5603-5621. [CrossRef]

3. Neppalli, R.; Marega, C.; Marigo, A.; Bajgai, M.P.; Kim, H.Y.; Causin, V. Poly(epsilon-caprolactone) filled with electrospun nylon fibres: A model for a facile composite fabrication. Eur. Polym. J. 2010, 46, 968-976. [CrossRef]

4. Venugopal, J.; Zhang, Y.Z.; Ramakrishna, S. Fabrication of modified and functionalized polycarbonate nanofiber scaffolds for vascular tissue engineering. Nanotechnology 2005, 16, 2138-2142. [CrossRef] [PubMed]

5. Jiang, S.; Chen, Y.; Duan, G.; Mei, C.; Greiner, A.; Agarwal, S. Electrospun nanofiber reinforced composites: A review. Polym. Chem. 2018. [CrossRef]

6. Lee, K.H.; Kim, H.Y.; Khil, M.S.; Ra, Y.M.; Lee, D.R. Characterization of nanostructured poly(epsilon-caprolactone) nonwoven mats via electrospinning. Polymer 2003, 44, 1208-1294. [CrossRef]

7. Moghe, A.K.; Hufenus, R.; Hudson, S.M.; Gupta, B.S. Effect of addition of a fugitive salt on electrospinnability of poly(epsilon-caprolactone). Polymer 2009, 50, 3311-3318. [CrossRef]

8. Li, W.; Tuli, R.; Okafor, C.; Derfoul, A.; Danielson, K.G.; Hall, D.J. A three dimensional nanofibrous scaffold for cartilage tissue engineering using human mesenchymal stem cells. Biomaterials 2005, 26, 599-609. [CrossRef]

9. Shin, M.; Ishii, O.; Sueda, T.; Vacanti, J.P. Contractile cardiac grafts using a novel nanofibrous mesh. Biomaterials 2004, 25, 3717-3723. [CrossRef]

10. Gaumer, J.; Prasad, A.; Lee, D.; Lannutti, J. Structure-function relationship and source-to-ground distance in electrospun polycaprolactone. Acta Biomater. 2009, 5, 1552-1561. [CrossRef] [PubMed]

11. Del Gaudio, C.; Bianco, A.; Folin, M.; Baiguera, S.; Grigioni, M. Structural characterization and cell response evaluation of electrospun PCL membranes: Micrometric versus submicrometric fibers. J. Biomed. Mater. Res. A 2009, 89A, 1028-1039. [CrossRef] [PubMed]

12. Yu, H.; Jang, J.; Kim, T.; Lee, H.; Kim, H. Apatite-mineralized polycarbonate nanofibrous web as a bone tissue regeneration substrate. J. Biomed. Mater. Res. A 2009, 88A, 747-754. [CrossRef] [PubMed]

13. Lie, X.; Xie, J.; Yuan, X.; Xia, Y. Coating electrospun poly( $\varepsilon$-caprolactone) fibers with gelatin and calcium phosphate and their use as biomimetric scaffolds for bone tissue engineering. Langmuir 2008, 24, 14145-14150. [CrossRef] [PubMed]

14. Lowery, J.L.; Datta, N.; Rutledge, G.C. Effect of fiber diameter, pore size and seeding method on growth of human dermal fibroblasts in electrospun poly(epsilon-caprolactone) fibrous mats. Biomaterials 2010, 31, 491-504. [CrossRef] [PubMed]

15. Prabhakaran, M.P.; Venugopal, J.; Chan, C.K.; Ramakrishna, S. Surface modified electrospun nanofibrous scaffolds for nerve tissue engineering. Nanotechnology 2008, 19, 1725-1731. [CrossRef] [PubMed]

16. Formhals, A. Process and Apparatus for Preparing Artificial Thread. U.S. Patent 1,975,504, 2 October 1934.

17. Feltz, K.P.; Growney Kalaf, E.A.; Chen, C.C.; Martin, R.S.; Sell, S.A. A review of electrospinning manipulation techniques to direct fier deposition and maximize pore size. De Gruyter Open 2017, 1, 46-61. 
18. Rojas-Mercado, A.S.; Moreno-Cortez, I.E.; Lucio-Porto, R.L.; López Pavón, L.L. Encapsulation and immobilization of ficin extract in electrospun polymeric nanofibers. Int. J. Biol. Macromol. 2018, 118, 2287-2295. [CrossRef]

19. Kalantari, K.; Afifi, A.M.; Jahangirian, H.; Webster, T.J. Biomedical applications of chitosan electrospun nanofibers as a green Polymer. Carbohydr. Polym. 2019, 207, 588-600. [CrossRef]

20. Wang, S.; Hu, F.; Li, J.; Zhang, S.; Shen, M.; Huang, M.; Shi, X. Design of electrospun nanofibrous mats for osteogenic differentiation of mesenchymal stem cells. Nanotechnol. Biol. Med. 2018, 14, 2505-2520. [CrossRef]

21. Wang, C.; Sun, S.; Zhang, L.; Yin, J.; Jiao, T.; Zhang, L.; Xu, Y.; Zhou, J.; Peng, Q. Facile preparation and catalytic performance characterization of AuNPs-loaded hierarchical electrospun composite fiers by solvent vapor annealing treatment. Colloids Surf. A. 2019, 561, 283-291. [CrossRef]

22. Yun, B.J.; Kwon, J.E.; Lee, K.; Koh, W.-G. Highly sensitive metal-enhanced florescence biosensor prepared on electrospun fiers decorated with silica-coated silver nanoparticles. Sens. Actuators B Chem. 2019, 284, 140-147. [CrossRef]

23. Hivechi, A.; Bahrami, S.H.; Siegel, R.A. Investigation of morphological, mechanical and biological properties of cellulose nanocrystal reinforced electrospun gelatin nano fibers. Int. J. Biol. Macromol. 2019, 124, 411-417. [CrossRef]

24. Ray, S.S.; Chen, S.-S.; Li, C.W.; Nguyen, N.C.; Nguyen, H.T. A comprehensive review: Electrospinning technique for fabrication and surface modification of membranes for water treatment application. RSC Adv. 2016, 6, 85495-85514. [CrossRef]

25. Li, J.-J.; Yang, Y.-Y.; Yu, D.-G.; Du, Q.; Yang, X.-L. Fast dissolving drug delivery membrane based on the ultra-thin shell of electrospun core-shell nanofibers. Eur. J. Pharm. Sci. 2018, 122, 195-204. [CrossRef] [PubMed]

26. Sukigara, S.; Gandhi, M.; Ayutsede, J.; Micklus, M.; Ko, F. Regeneration of Bombyx mori silk by electrospinning-part 1: Processing parameters and geometric properties. Polymer 2003, 44, 5721-5727. [CrossRef]

27. Fadaie, M.; Mirzaei, E.; Geramizade, B.; Asvar, Z. Incorporation of nanofibrillated chitosan into electrospun PCL nanofibers makes scaffolds with enhanced mechanical and biological properties. Carbohydr. Polym. 2018, 199, 628-640. [CrossRef] [PubMed]

28. Alali, K.T.; Liu, J.; Aljebawi, K.; Liu, Q.; Chen, R.; Yu, J.; Zhang, M.; Wang, J. 3D hybrid Ni-Multiwall carbon nanotubes/carbon nanofibers for detecting sarin nerve agent at room temperature. J. Alloys Compd. 2019, 780, 680-689. [CrossRef]

29. Yang, G.; Li, X.; He, Y.; Ma, J.; Ni, G.; Zhou, S. From nano to micro to macro: Electrospun hierarchically structured polymeric fibers for biomedical applications. Prog. Polym. Sci. 2018, 81, 80-113. [CrossRef]

30. Kiran, A.S.K.; Kumar, T.S.S.; Perumal, G.; Sanghavi, R.; Doble, M.; Ramakrishna, S. Dual nanofibrous bioactive coating and antimicrobial surface treatment for infection resistant titanium implants. Prog. Org. Coat. 2018, 121, 112-119. [CrossRef]

31. Quiros, J.; Boltes, K.; Rosal, R. Biactive applications for electrospun fibers. Polym. Rev. 2016, 56, 631-667. [CrossRef]

32. Hou, L.; Zhang, X.; Mikael, P.E.; Lin, L.; Dong, W.; Zheng, Y.; Simmons, T.J.; Zhang, F.; Linhardt, R.J. Biodegradable and bioactive PCL-PGS core-shell fibers for tissue engineering. ACS Omega 2017, 2, 6321-6328. [CrossRef] [PubMed]

33. Xie, J.; Li, X.; Xia, Y. Putting electrospun nanofibers to work for biomedical research. Macomol. Rapid Commun. 2008, 29, 1775-1792. [CrossRef]

34. Deliormanli, A.M.; Konyali, R. Preparation of mineralization of 13-93 bioactive glass-containing electrospun poly-epsilo-caprolactone composite nanofibrous mats. J. Thermoplast. Compos. Mater. 2018, 32, 1-20.

35. Miguel, P.S.; Ribeiro, M.P.; Coutinho, P.; Correia, I.J. Electrospun polycaprolactone/aloe vera chitosan nanofibrous asymmetric membranes aimed for wound healing applications. Polymers 2017, 9, 183. [CrossRef]

36. Ramirea-Cedillo, E.; Ortega-Lara, W.; Rocha-Pizana, M.R.; Gutierrez-Uribe, J.A.; Elias-Zuniga, A.; Rodriguez, C.A. Electrospun polycaprolactone fibrous membranes containing $\mathrm{Ag}, \mathrm{TiO}_{2}$ and $\mathrm{Na}_{2} \mathrm{Ti}_{6} \mathrm{O}_{13}$ particles for potential use in bone regeneration. Membranes 2019, 9, 12.

37. Li, W.; Shi, L.; Zhang, X.; Liu, K.; Ullah, I.; Cheng, P. Electrospinning of polycaprolactone nanofibers using $\mathrm{H}_{2} \mathrm{O}$ as benign additive in polycaprolactone/glacial acetic solution. J. Appl. Polym. Sci. 2017, 143, 45578. 
38. Ekram, B.; Abdel-Hady, B.M.; El-Kady, A.M.; Amr, S.M.; Waley, A.I.; Gurguis, O.W. Optimum parameters for the production of nanoscale electrospun polycaprolactone to be used as a biomedical material. Adv. Nat. Sci. Nanosci. Nanotechnol. 2017, 8, 045018. [CrossRef]

39. Croisier, F.; Duwez, A.-S.; Jérôme, C.; Léonard, A.F.; van der Werf, K.O.; Dijkstra, P.J.; Bennink, M.L. Mechanical testing of electrospun PCL fibers. Acta Biomater. 2012, 8, 218-224. [CrossRef]

40. Baker, S.R.; Banerjee, S.; Bonin, K.; Guthold, M. Determining the mechanical properties of electrospun

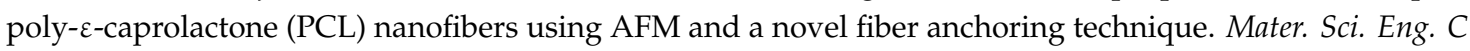
2016, 59, 203-212. [CrossRef]

41. Balakrishnan, P.B.; Gardella, L.; Forouharshad, M.; Pellegrino, T.; Monticelli, O. Star poly( $\varepsilon$-caprolactone)-based electrospun fibers as biocompatible scaffold for doxorubicin with prolonged drug release activity. Colloids Surf. B 2018, 161, 488-496. [CrossRef]

42. Katsogiannis, K.A.G.; Vladisavljević, G.T.; Georgiadou, S. Porous electrospun polycarbonate (PCL) fibres by phase separation. Eur. Polym. J. 2015, 69, 284-295. [CrossRef]

43. Wang, X.; Zhao, H.; Turng, L.-S.; Li, Q. Crystalline morphology of electrospun poly(e-caprolactone) (PCL) nanofibers. Ind. Eng. Chem. Res. 2013, 52, 4939-4949. [CrossRef]

44. Qin, X.; Wu, D. Effect of different solvents on poly(caprolactone) (PCL) electrospun nonwoven membranes. J. Therm. Anal. Calorim. 2012, 107, 1007-1013. [CrossRef]

45. Hassan, M.I.; Sun, T.; Sultana, N. Fabrication of nanohydroxyapatite/poly(carbonate) composite microfibers using electrospinning technique for tissue engineering applications. J. Nanomater. 2014, 2014, 1-7.

46. Surucu, S.; Sasmazel, H.T. Development of core-shell coaxially electrospun composite PCL/chitosan scaffold. Int. J. Macromol. 2016, 92, 321-328. [CrossRef]

47. Shalumon, K.T.; Anulekha, K.H.; Girish, C.M.; Prasanth, R.; Nair, S.V.; Jayakumar, R. Single step electrospinning of chitosan/polycaprolactone nanofibers using formic acid/acetone solvent mixture. Carbohydr. Polym. 2010, 80, 413-419. [CrossRef]

48. Hanas, T.; Sampath Kumar, T.S.; Perumal, G.; Doble, M.; Ramakrishna, S. Electrospun PCL/HA coated friction stir processed AZ31/HA composites for degradable implant applications. J. Mater. Process Technol. 2018, 252, 398-406.

49. Ke, R.; Yi, N.; Tao, S.; Wen, Y.; Hongyu, Z. Electrospun PCL/gelatin composite nanofiber structures for effective guided bone regeneration membranes. Mater. Sci. Eng. C 2017, 78, 324-332.

50. Dulnik, J.; Denis, P.; Sajkiewicz, P.; Kolbuk, D.; Choińska, E. Biodegradation of biocomponent PCL/gelatin and PCL/collagen nanofibers electrospun from alternative solvent system. Polym. Degrad. Stab. 2016, 130, 10-21. [CrossRef]

51. Gong, M.; Chi, C.; Ye, J.; Liao, M.; Xie, W.; Wu, C.; Shi, R.; Zhang, L. Icariin-loaded electrospun PCL/gelatin nanofiber membrane as potential artificial periosteum. Colloids Surf. B Bionterfaces 2018, 170, 201-209. [CrossRef] [PubMed]

52. Hivechi, A.; Bahrami, S.H.; Siegel, R.A. Drug release and biodegradability of electrospun cellulose nanocrystal reinforced polycaprolactone. Mater. Sci. Eng. C 2019, 94, 929-937. [CrossRef]

53. Houshyar, S.; Kumar, G.S.; Rifai, A.; Tran, N.; Nayak, R.; Shanks, R.A.; Padhye, R.; Fox, K.; Bhattacharyya, A. Nanodiamond/poly- $\varepsilon$-caprolactone nanofibrous scaffold for wound management. Mater. Sci. Eng. C 2019, 100, 378-387. [CrossRef] [PubMed]

54. Aydogdu, M.O.; Ekren, N.; Suleymanoglu, M.; Erdem-Kuruca, S.; Lin, C.-C.; Bulbul, E.; Erdol, M.N.; Oktar, F.N.; Terzi, U.K.; Kilic, O.; et al. Novel electrospun polycaprolactone/graphene oxide $/ \mathrm{Fe}_{3} \mathrm{O}_{4}$ nanocomposites for biomedical applications. Colloids Surf. B 2018, 172, 718-727. [CrossRef]

55. Zhang, X.; Wang, C.; Liao, M.; Dai, L.; Tang, Y.; Zhang, H.; Coates, P.; Sefat, F.; Zheng, L.; Song, J.; et al. Aligned electrospun cellulose scaffolds coated with rhBMP-2 for both in vitro and in vivo bone tissue engineering. Carbohydr. Polym. 2019, 213, 27-38. [CrossRef] [PubMed]

56. Mahboobeh, A.-S.; Mohammad, M.Y.; Masoud, T.-M.; Masoumeh, D. Controlled release of lawsone from polycaprolactone/gelatin electrospun nano fibers for skin tissue regeneration. Int. J. Biol. Macromol. 2019, 124, 478-491.

57. Wang, Y.; Cui, W.; Chouc, J.; Wen, S.; Sun, Y.; Zhang, H. Electrospun nanosilicates-based organic/inorganic nanofibers for potential bone tissue engineering. Colloids Surf. B 2018, 172, 90-97. [CrossRef]

58. Nazeer, M.A.; Yilgor, E.; Yilgor, I. Electrospun polycaprolactone/silk fibroin nanofibrous bioactive scaffolds for tissue engineering applications. Polymer 2019, 168, 86-94. [CrossRef] 
59. Lee, J.M.; Chae, T.; Sheikh, F.A.; Ju, H.W.; Moon, B.M.; Park, H.J.; Park, Y.R.; Park, C.H. Three dimensional poly ( $\varepsilon$-caprolactone) and silk fibroin nanocomposite fibrous matrix for artificial dermis. Mater. Sci. Eng. C 2016, 68, 758-767. [CrossRef]

60. Chaparro, F.J.; Presley, K.F.; Coutinho da Silva, M.A.; Lannutti, J.J. Sintered electrospun polycaprolactone for controlled model drug delivery. Mater. Sci. Eng. C 2019, 99, 112-120. [CrossRef]

61. Heidari, M.; Bahrami, H.; Ranjbar-Mohammadi, M. Fabrication, optimization and characterization of electrospun poly(caprolactone)/gelatin/graphene nano fibrous mats. Mater. Sci. Eng. C 2017, 78, $218-229$. [CrossRef] [PubMed]

62. Rad, Z.P.; Mokhtari, J.; Abbasi, M. Fabrication and characterization of PCL/zein/gum arabic electrospun nanocomposite scaffold for skin tissue engineering. Mater. Sci. Eng. C 2018, 93, 356-366.

63. Sepahvandi, A.; Eskandari, M.; Moztarzadeh, F. Fabrication and characterization of $\mathrm{SrAl}_{2} \mathrm{O}_{4}: \mathrm{Eu}^{2+}$ $\mathrm{Dy}^{3+} / \mathrm{CS}-\mathrm{PCL}$ electrospun nanocomposite scaffold for retinal tissue regeneration. Mater. Sci. Eng. C 2016, 66, 306-314. [CrossRef] [PubMed]

64. Shafiei, S.S.; Shavandi, M.; Ahangari, G.; Shokrolahi, F. Electrospun layered double hydroxide/poly ( $\varepsilon$-caprolactone) nanocomposite scaffolds for adipogenic differentiation of adipose-derived mesenchymal stem cells. Appl. Clay Sci. 2016, 127, 52-63. [CrossRef]

65. Perumal, G.; Ramasamy, B.; Nandkumar, A.M.; Doble, M. Nanostructure coated AZ31 magnesium cylindrical mesh cage for potential long bone segmental defect repair applications. Colloids Surf. B 2018, 172, $690-698$. [CrossRef] [PubMed]

66. Prado-Prone, G.; Silva-Bermudez, P.; Almaguer-Flores, A.; García-Macedo, J.A.; García, V.I.; Rodil, S.E.; Ibarra, C.; Velasquillo, C. Enhanced antibacterial nanocomposite mats by coaxial electrospinning of polycaprolactone fibers loaded with Zn-based nanoparticles. Nanomed. NBM 2018, 14, 1695-1706. [CrossRef]

67. Aguirre-Chagala, Y.E.; Altuzar, V.; León-Sarabia, E.; Tinoco-Magaña, J.C.; Yañez-Limón, J.M.; Mendoza-Barrera, C. Physicochemical properties of polycaprolactone/collagen/elastin nano fibers fabricated by electrospinning. Mater. Sci. Eng. C 2017, 76, 897-907. [CrossRef]

68. Gönen, S.O.; Taygun, M.E.; Aktürk, A.; Küçükbayrak, S. Fabrication of nanocomposite mat through incorporating bioactive glass particles into gelatin/poly( $\varepsilon$-caprolactone) nano fibers by using Box-Behnken design. Mater. Sci. Eng. C 2016, 67, 684-693. [CrossRef]

69. Shoba, E.; Lakra, R.; Kiran, M.S.; Korrapati, P.S. Strategic design of cardiac mimetic core-shell nanofibrous scaffold impregnated with Salvianolic acid B and Magnesium L-ascorbic acid 2-phosphate for myoblast differentiation. Mater. Sci. Eng. C 2018, 90, 131-147. [CrossRef]

70. Gönen, S.O.; Taygun, M.E.; Küçükbayrak, S. Fabrication of bioactive glass containing nanocomposite fiber mats for bone tissue engineering applications. Compos. Struct. 2016, 138, 96-106. [CrossRef]

71. Kim, J.I.; Kim, C.S. Harnessing nanotopography of PCL/collagen nanocomposite membrane and changes in cell morphology coordinated with wound healing activity. Mater. Sci. Eng. C 2018, 91, 824-837. [CrossRef]

72. Dumitriu, R.P.; Mitchell, G.R.; Davis, F.J.; Vasile, C. Functionalized Coatings by Electrospinning for Anti-oxidant Food Packaging. Procedia Manuf. 2017, 12, 59-65. [CrossRef]

73. Wu, G.; Deng, X.; Song, J.; Chen, F. Enhanced biological properties of biomimetic apatite fabricated polycaprolactone/chitosan nanofibrous bio-composite for tendon and ligament regeneration. J. Photochem. Photobiol. B 2018, 178, 27-32. [CrossRef]

74. Hu, W.-W.; Ting, J.-C. Gene immobilization on alginate/polycaprolactone fibers through electrophoretic deposition to promote in situ transfection efficiency and biocompatibility. Int. J. Biol. Macromol. 2019, 121, 1337-1345. [CrossRef] [PubMed]

75. Hu, W.-W.; Hu, Z.-C. The control of alginate degradation to dynamically manipulate scaffold composition for in situ transfection application. Int. J. Biol. Macromol. 2018, 117, 1169-1178. [CrossRef] [PubMed]

76. Hu, W.-W.; Wu, Y.-C.; Hu, Z.-C. The development of an alginate/polycaprolactone composite scaffold for in situ transfection application. Carbohydr. Polym. 2018, 183, 29-36. [CrossRef] [PubMed]

77. Marrella, A.; Tedeschi, G.; Giannoni, P.; Lagazzo, A.; Sbrana, F.; Barberis, F.; Quarto, R.; Puglisi, F.; Scaglione, S. "Green-reduced" graphene oxide induces in vitro an enhanced biomimetic mineralization of polycaprolactone electrospun meshes. Mater. Sci. Eng. C 2018, 93, 1044-1053. [CrossRef]

78. McInnes, S.J.; Macdonald, T.J.; Parkin, I.P.P.; Nann, T.; Voelcker, N.H. Electrospun Composites of Polycaprolactone and Porous Silicon Nanoparticles for the Tunable Delivery of Small Therapeutic Molecules. Nanomaterials 2018, 8, 205. [CrossRef] [PubMed] 
79. Zanetti, M.; Mazon, L.R.; de Meneses, A.C.; Silva, L.L.; de Araújo, P.H.H.; Fiori, M.A.; de Oliveira, D. Encapsulation of geranyl cinnamate in polycaprolactone nanoparticles. Mater. Sci. Eng. C 2019, 97, 198-207. [CrossRef] [PubMed]

80. Kaffashi, B.; Davoodi, S.; Oliaei, E. Poly(e-caprolactone)/triclosan loaded polylactic acid nanoparticles composite: A long-term antibacterial bionanocomposite with sustained release. Int. J. Pharm. 2016, 508, 10-26. [CrossRef] [PubMed]

81. Repanas, A.; Bader, A.; Klett, A.; Ngezahayo, A.; Glasmacher, B. The effect of dipyridamole embedded in a drug delivery system made by electrospun nanofibers on aortic endothelial cells. J. Drug Deliv. Sci. Technol. 2016, 35, 343-352. [CrossRef]

82. Wu, B.; Yang, Y.; Shi, J.; Chang, S.; Li, S.; Lu, W.F.; Trau, D.; Fuh, J.Y.H. A biologically inspired hierarchical PCL/F127 scaffold for esophagus tissue repair. Mater. Lett. 2019, 243, 132-135. [CrossRef]

83. Tiwari, A.P.; Joshi, M.K.; Kim, J.I.; Unnithan, A.R.; Lee, J.; Park, C.H.; Kim, C.S. Bimodal fibrous structures for tissue engineering: Fabrication, characterization and in vitro biocompatibility. J. Colloid Interface Sci. 2016, 476, 29-34. [CrossRef] [PubMed]

84. Nadim, A.; Khorasani, S.N.; Kharaziha, M.; Davoodi, S.M. Design and characterization of dexamethasone-loaded poly (glycerolsebacate)-poly caprolactone/gelatin scaffold by coaxial electro spinning for soft tissue engineering. Mater. Sci. Eng. C 2017, 78, 47-58. [CrossRef] [PubMed]

85. Chou, S.-F.; Woodrow, K.A. Relationships between mechanical properties and drug release from electrospun fibers of PCL and PLGA blends. J. Mech. Behav. Biomed. Mater. 2017, 65, 724-733. [CrossRef]

86. Holmes, B.; Fang, X.; Zarate, A.; Keidar, M.; Zhang, L.G. Enhanced human bone marrow mesenchymal stem cell chondrogenic differentiation in electrospun constructs with carbon nanomaterials. Carbon 2016, 97, 1-13. [CrossRef]

87. Deng, S.; Ma, J.; Guo, Y.; Chen, F.; Fu, Q. One-step modification and nanofibrillation of microfibrillated cellulose for simultaneously reinforcing and toughening of poly(e-caprolactone). Compos. Sci. Technol. 2018, 157, 168-177. [CrossRef]

88. Chlanda, A.; Kijeńska, E.; Rinoldi, C.; Tarnowski, M.; Wierzchoń, T.; Swieszkowski, W. Structure and physico-mechanical properties of low temperature plasma treated electrospun nanofibrous scaffolds examined with atomic force microscopy. Micron 2018, 107, 79-84. [CrossRef] [PubMed]

89. Daelemans, L.; Steyaert, I.; Schoolaert, E.; Goudenhooft, C.; Rahier, H.; De Clerck, K. Nanostructured Hydrogels by Blend Electrospinning of Polycaprolactone/Gelatin Nanofibers. Nanomaterials 2018, 8, 551. [CrossRef] [PubMed]

(C) 2019 by the authors. Licensee MDPI, Basel, Switzerland. This article is an open access article distributed under the terms and conditions of the Creative Commons Attribution (CC BY) license (http://creativecommons.org/licenses/by/4.0/). 